\title{
Factors Analysis of Self-Efficacy Outcome Expectations In Influencing The Commitment And Performance Of Information Technology End Users
}

\author{
Enny Radjab
}

\begin{abstract}
Research proceeds with the background that the acceptance and utilization of information technology will facilitate increasing work achievement's effectiveness and efficiency. Other than computer, end user's attitude and behavior also becomes important factor contributing to information technology's acceptance and utilization.

The objective of research aims to explain that: (1) knowledge, technical support, and usage facilitation, affect computer self-efficacy; (2) knowledge, technical support, and usage facilitation provide prominence effect; (3) computer self-efficacy affects output expectation, commitment, and end user performance; (4) output expectation affects commitment and end user performance; and (5) commitment affects end user performance.

Research examines the relationship between variables such that may be called as explanatory research. Research locates at Makassar City as targeted population of public and private higher education where information technology seems used. Twelve (12) higher educations in Makassar City have applied information technology. Research population includes the employee having direct interaction with information technology at twelve higher educations, as much as 684 persons. The sample used reaches about 423 persons by three (3) strata: University, Institution, and Polytechnic. Statistic Analysis used to test hypotheses considers Structural Equation Model, SEM.

Results of research indicate that there remain twelve (12) direct and indirect relationship channels, nine (9) significant relationship channels and three (3) insignificant relationship channels. Nine (9) significant relationship channels show that: (1) knowledge affects computer self-efficacy; (2) technical support affects computer self-efficacy; (3) information technology usage facilitation affects computer self-efficacy; (4) technical support affects output expectation; (5) computer self-efficacy affects output expectation; (6) computer selfefficacy affects end user performance; (7) output expectation affects end user commitment; (8) output expectation affects end user performance; and (9) commitment affects end user performance. Meanwhile, three (3) insignificant relationship channels display that: (1) knowledge affects output expectation; (2) computer selfefficacy affects end user commitment, and (3) commitment affects end user performance.
\end{abstract}

Keywords: Information Technology, Higher Education, Knowledge, Technical Support, Usage Facilitation, Computer Self-Efficacy, Output Expectation, Commitment, and Performance.

\subsection{Research Background}

\section{Introduction}

The use of information technology (IT) in various forms of appropriate applications, will greatly assist to improve the efficiency and effectiveness of work completion. So IT will have a positive impact for the end users if the technology is in accordance with the individual tasks and used optimally. As do in educational institutions such as universities which are also modern organizations that perform activities using IT. Information Technology is considerably helpful in learning activities in universities, particularly in universities that possess integrated Information Systems and Information Technology in all work units (fully computerized). However, the implementation of these activities is not only depend on computer technology, but also with regard to the level of individual skill or behavior that affecting IT.

Aspects of end user attitudes are important factors that contribute to the acceptance of IT. Johan and Wijaya (2005) argued that every individual will react positively toward the presence of computer technology if the benefit (perceived usefulness) of of it is to improve performance and productivity, and the benefits perceived by end users due to the ability of each individual to operate a computer.

Attitudes and behavior of end users toward the use and acceptance of a new IT have been acknowledged by researchers and expressed as major factors in the successful use. The more the acceptance of new IT by end users, the more the willingness of end users to make long-term changes in practice, both in use as well as integrating new IT into their daily work activities.

In order to estimate and explain the acceptance and utilization of new IT by end users in influencing the behavior of the end user in positive manners, many researchers have uses variety of models based on expectation behavioral models in the social sciences. Among these, Theory acceptance model of Davis (1986), 
which is based on the Theory of Reasoned Action of Fishbein and Ajzen, and individual perception proposed by Bandura (1986), which describes the process by which individuals acquire self-efficacy and outcome expectations

Research on self-efficacy and outcome expectations had been widely carried out. In those studies, selfefficacy and outcome expectations associated with some effect variables, one of which is commitment of end user (Malhotra and Galletta; 2005). Many studies have examined organizational commitment and it's antecedent in the social sciences and the context of organizational behavior, but little attention has been given to the end users IT work commitments. The manner to identify end-user organizational commitment shall facilitate the development of end-user involvement in removing end-user resistance to the system and this will lead to enhanced end-user commitment (Warcock, Matherson and Plummer, 1980 in Stone and Henry, 2003).

Furthermore, from the attitudes and behavior of end users on IT, especially in the utilization and use of IT, those end users shall able to improve their performance. Research related to end-user performance had been widely done. One of which conducted by Jawahar and Elango (2001) that stated that managers can improve their performance by enhancing confidence in computer self-efficacy of end users. Computer self-efficacy of end users can be improved through direct experience, learn from others' experiences, and verbal persuasion.

Based on the limitations of some previous studies, this research is conducted to understand the relationship model which completely includes the variables of Information Technology, technical support, ease of system use, computer self-efficacy, outcome expectations, commitment and performance of Information Technolofy end users. For the purposes of testing the structural model, the employees who work and interact directly with the use of IT in Higher Education will be asked to participate in this study.

Based on the explanation above, then shall be conducted research under the title "The Role of

Antecedent Variables of Self-Efficacy Outcome Expectations in Influencing the Commitment and Performance of Information Technology End Users", by conducting the study regarding the application of information technology in Universities in Makassar City.

\subsection{Research Issues}

Based on the description of research background, then it is formulated several following issues:

1. Is the antecedent variables influence the computer self-efficacy?

2. Is the antecedent variables influence the outcome expectations?

3. Is computer self-efficacy influence the outcome expectations, commitment and performance of information technology end users?

4. Is outcome expectations influence the commitment and performance of Information Technology end users?

5. Is the end-user commitment influence end-user performance?

\subsection{Research Purpose}

The purposes of the research are:

1. To explain that the antecedent variables have influence on computer self-efficacy

2. To explain that the antecedent variables have influence on outcome

3. To explain that computer self-efficacy have influence on outcome expectations, commitment and performance of the end users.

4. To explain that outcome expectations have influence on end-user commitment and performance.

5. To explain that commitment of end users have influence on end-user.

\subsection{Research Benefits}

The benefits obtained from this research can be grouped into two categories, namely scientific category and practical category. For scientific categories:

1. For additional empirical evidence regarding the existence of information technology end users behaviour which can be used as indicator in the acceptance and use of information technology.

2. As a discourse repertoire of knowledge, particularly in developing end-user behaviors associated with information technology implementation and use of Management Information Systems (MIS) and Information Technology (IT) as well as to provide insight for policy makers regarding to end users acceptance to the presence of new information technology.

Whereas for practical benefits:

1. As a contribution for administrative employees who use information technology whereas computer selfefficacy will affect their ability to use computer, which in turn will affect their performance and commitment in the use of information technology. 
2. As a useful contribution to Universities for better development of information technology.

3. As a contribution to a deeper understanding of the study of behavior problems associated with the use of information technology.

4. As a reference of scientific writing for those who interested in further research, particularly in the field of information systems development.

\subsection{Antecedent Variables}

\section{Literature Review}

Antecedent variables that affect computer self-efficacy and outcome expectations are:

\section{Knowledge}

Knowledge of Information Technology (IT) is a necessary resource in the process of acceptance and utilization of IT. Knowledge consists of capabilities and skills of end users to IT. Capabilities and skills acquired from education and training levels that have been followed with regard to IT.

In general, education related to preparation of human resource candidates required by an instance or organization, while training is more concerning with increasing capabilities or skills of employees who have occupied a particular job or task.

\section{Technical Support}

Technical support represent the need and support for end-users in the use of new software applications which is expected to enhance the ability of end-user development (McQueen and Mills, 1998). Support is one of the main factors for computer application as proposed by Compeau and Higgins (1995), that the technical support provided by organization to use computer is measured from indicators of amount of support or assistance facilities which are available in the selection of equipment, to overcome difficulties regarding hardware and software. Igbaria (1990) conveyed that the support plays an important role in introducing endusers on new devices and in responding to the needs of end users as well as in responding problems.

\section{The Ease of Information Technology Use}

Ease of use is described as "the degree to which a person believes that using a particular system would be free from mental and physical efforts" (Davis, 1989). Davis also said that ease of use is one important factor in determining the use of operating system through Perceived Benefits Perception. Goodwin (1987) argued that the effective ability of a system, which is Perceived Benefits Perception depends on it's ability, namely ease of use. Davis (1993) stated that ease of use is the main cause of Perceived Benefit Perception. Technology Acceptance Model postulates that ease of use of a system is an important determinant

\subsection{Relationship between Self-efficacy and Outcome Expectation}

Some of the latest models for the use of information technology prediction focus on self-efficacy and outcome expectations as main antecedent of behavior (Henry and Stone, 1995; Compeau, Higgins, and Huff, 1999). The relationship between self-efficacy and outcome expectations also treated intensively (Henry and Stone, 1997). Figure 2.1 illustrates a model where e1 and e2 are the effects of self-efficacy and outcome expectations on behavior. By stating that in most of experiments, the outcome closely related to performance, a strong correlation could be found between outcome expectations and self-efficacy (e3). It also supports the hypothesis Bandura (1986) that when performance determines performance outcomes, self-efficacy is a strong predictor of performance. This effort, even so, result in the belief that outcome expectations is not relevant to predict acceptance of information technology (maracas, et al., 1998).

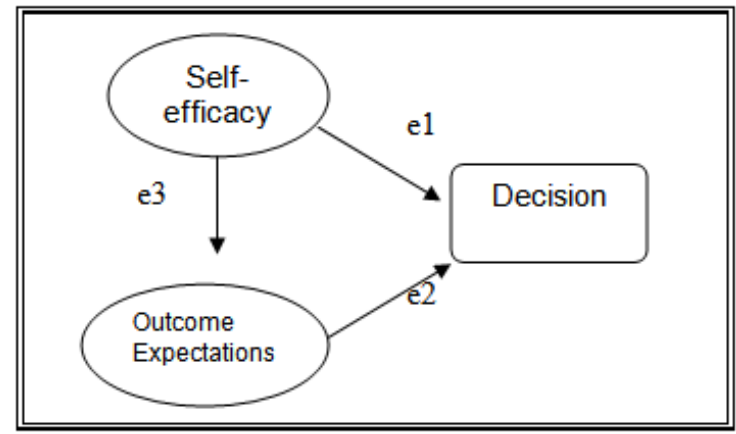

Figure 2.1 Prediction Model of Social Cognitive Source: Maller (2000) 
Perceived self-efficacy and outcome expectations is different, and can potentially act differently. For example, Jane might consider that money and fame of professional athletes can be very interesting (outcome expectations), but she will not achieve a professional athletic career unless she is able to assess herself capable of performing acceptable performance (self-efficacy). In addition, she can judge herself capable to go to class wearing a clown costume (self-efficacy), but she would not do it if the consequences are not desirable (outcome expectations). Bandura ( 1997 ) synthesizes this relationship by saying that "people have the confidence to take action when the efficacy and outcome expectations made their efforts valuable". Since the results derived from performance, the same temporal relationship can be determined cognitively; outcome expectations depend on beliefs about the level of performance that he/she is capable of (Figure 2.2.). Students who see themselves "incapable" to use a computer will see themselves as failure in the computer courses.

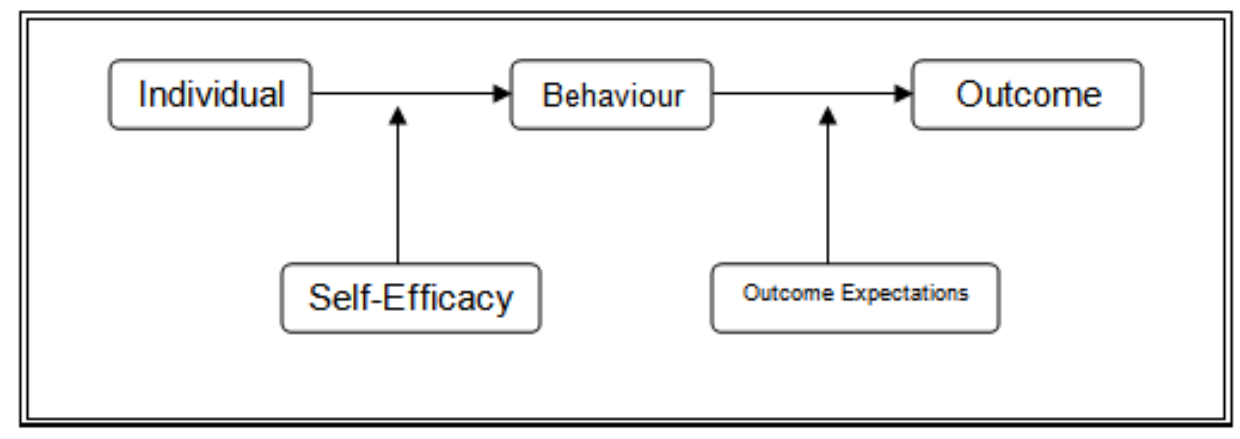

Figure 2.2 Relationship between Self-efficacy and Outcome Expectations Source: Maller (2000)

The relationship between outcome expectations and self-efficacy can be attenuated by context, that led to the split point. It occurs when the result is less related to the level of performance. Some external components of outcome expectations is influenced, while self-control mechanism can still affect the overall outcome expectations. Another example is when the result set at certain level of performance. However the perceived ability of individual, external motivation can be given the same after particular tagging. Motivator that persists in the behavior in this case can be attributed to the expectations of internal expectation outcomes, such as selfhonor, or other factors in environment such as pressure from parents. Performance and self-efficacy are generally less associated with this condition.

\subsection{Commitment of End Users}

According to Malhotra and Galletta (2005) commitment is conceptualized into two dimensions, namely:

1. Affective Commitment

Affective commitment is system user commitment based on individual values suitability and identification of determined user satisfactory relationship. There are two kind of affective commitments, namely: Internalizationbased commitment and Identification-based commitment.

2. Continuance Commitment

Continuance Commitment based on cost, by system users associated with not adopting the cause of the behavior.

\subsection{Performance of End Users}

Performance is essentially what is performed or not performed by employee. While the employee's performance is the work result accomplished by an employee or organization in performing duties accorting the responsibility authority given, including: job quantity, job quality, job completion period, job attendance, and cooperative attitude. Job performance is the result of work achieved by an employee in carrying out duties and responsibilities and work according to the authority given.

\section{Research Methodology}

This study uses an explanatory pattern which intends to explain the position of variables studied and the relationship and influence of one variable with another.

The research location selected is Makassar City with target population of Makassar public and private Universities that using information technology for at least one system, such as SIAKAD.

The population in this study are all end users of information technology in central offices of both public and private Universities, Colleges and Polytechnics in Makassar, numbering 684.

Characteristics of study sample are end users of information technology in higher education (universities). Because the heterogeneous population has a significant meaning to the achievement of study 
objectives, for example, different types of colleges, we used a stratified proportional random sampling, of which first of all is subject withdrawal from each comparable college (proportional sampling). Furthermore, the samples are drawn by separating population group elements which are not overlaping called strata, and then selecting a random sample from each stratum (Arikunto, 1989).

The number of samples taken in this study is based on suggestion of Slovin (Umar, 2001) by using the formula:

$\mathrm{n}=\frac{N}{1+N(e)^{2}}$

\section{Keterangan:}

$\mathrm{n}=\quad$ Number of samples

$\mathrm{N}=$ Population

$\mathrm{e} \quad=\quad$ Persentage of leniency inaccuracy (precision) due to sampling error that can be tolerated

Based on above formula, the sample size obtaines is:

$\mathrm{n}=\frac{684}{1+(684)(0.03)^{2}}=423,4=423$

Types and data sources of the study consist of : Primary data and secondary data. The analytical method used is descriptive statistical analysis and inferential statistical analysis. Descriptive statistical analysis is used to describe the study variables, without withdrawing generalization. While the inferential statistical analysis used in the data analysis of this study is Structural Equation Modeling (SEM).

\subsection{Result of The Research}

\section{Result And Discussion Of The Research}

Based on method of determining value in the model, the first model testing variables are grouped into exogenous variables and endogenous variables. Exogenous variable is a variable whose value is determined outside the model. While the endogenous variable is a variable whose value is determined by an equation or established relationship model. Variables included within the exogenous group are Information Technology knowledge, technical support and ease of IT use while endogenous variables are classified as computer selfefficacy, outcome expectations, end user commitment and end-user performance.

The results of SEM analysis at later stages in complete are presented in appendix and output in the form of a path diagram presented as follows.

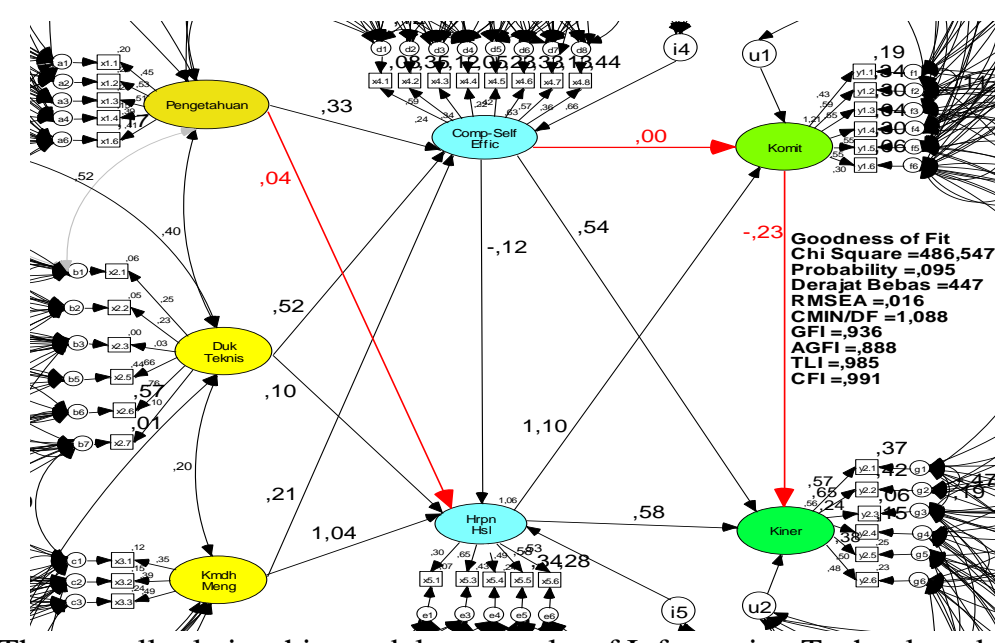

Figure 4.1. The overall relationship model test results of Information Technology knowledge, technical support, and ease of IT use variables toward computer self-efficacy, outcome expectations, edn user commitment and end user performance variables.

Final model test results presented in Figure 5.1 above are evaluated based on goodness of fit indices in Table 5.1 below by presenting the model criteria as well as the critical values which suitable with the data. 
Factors Analysis of Variables of Self-Efficacy Outcome Expectations in Influencing the...

Table 4.1 Evaluation of Goodness of Fit Indices Criteria of overall model

\begin{tabular}{|c|c|c|c|}
\hline Goodness of fit index & Cut-off Value & Model Result & Remarks \\
\hline Chi-square & Expected to be small & 486.547 & Good \\
\hline Probability & $\geq 0.05$ & 0.095 & Good \\
\hline CMIN/DF & $\leq 2.00$ & 1.088 & Good \\
\hline GFI & $\geq 0.90$ & 0.936 & Good \\
\hline AGFI & $\geq 0.90$ & 0.888 & Marginal \\
\hline TLI & $\geq 0.95$ & 0.985 & Good \\
\hline CFI & $\geq 0.95$ & 0.991 & Good \\
\hline RMSEA & $\leq 0,08$ & 0.016 & Good \\
\hline
\end{tabular}

Source: Hair (1992), Arbuckle (1997)

Evaluation of proposed model shows that the evaluation of overall models toward constructs based on various criterias turn out there is no critical violations except AGFI value which is still below the critical value, yet the value is closer to the critical value.

Analysis of direct effect, indirect effect, and total effect between constructs of the model can be compared to evaluate the effect of each construct on direct effect which is a coefficient of all coefficient lines with arrows one one end, whereas indirect effects are effects that arise through an intervening variable and total effect is the effects of various relationships (Augusty, 2005), the test results are presented as follows:

Table 4.2 Results of Research Hypotheses Test

\begin{tabular}{|c|c|c|c|c|c|c|c|}
\hline \multirow[t]{2}{*}{ HIP } & \multirow{2}{*}{$\begin{array}{c}\text { Independent } \\
\text { Variables }\end{array}$} & \multirow{2}{*}{$\begin{array}{c}\text { Dependent } \\
\text { Variables }\end{array}$} & \multicolumn{3}{|c|}{ Path Coeff. Effect } & \multirow[t]{2}{*}{ (p value) } & \multirow[t]{2}{*}{ Decision } \\
\hline & & & Direct & Indirect & Total & & \\
\hline $\mathrm{H} 1$ & Knowledge & Comp-Self_Effic & 0,331 & 0,000 & 0,331 & 0,002 & Accepted \\
\hline $\mathrm{H} 2$ & Tech_Support & Comp-Self_Effic & 0,522 & 0,000 & 0,522 & $* * *$ & Accepted \\
\hline $\mathrm{H} 3$ & Ease_of_Use & Comp-Self_Effic & 0,208 & 0,000 & 0,208 & 0,008 & Accepted \\
\hline $\mathrm{H} 4$ & Knowledge & Outcome_Expt. & 0,044 & 0,041 & 0,085 & 0,561 & Rejected \\
\hline $\mathrm{H} 5$ & Tech_Support & Outcome_Expt. & 0,105 & 0,065 & 0,170 & 0,001 & Accepted \\
\hline $\mathrm{H} 6$ & Ease_of_Use & Outcome_Expt. & 1,042 & 0,026 & 1,068 & $* * *$ & $\overline{\text { Accepted }}$ \\
\hline $\mathrm{H} 7$ & Comp-Self_Effic & Outcome_Expt. & 0,124 & 0,000 & 0,124 & 0,034 & Accepted \\
\hline $\mathrm{H} 8$ & Comp-Self_Effic & Commitment & $-0,004$ & 0,136 & 0,132 & 0,946 & Rejected \\
\hline $\mathrm{H} 9$ & Comp-Self_Effic & Performance & 0,538 & 0,036 & 0,574 & $* * *$ & Accepted \\
\hline $\mathrm{H} 10$ & Outcome_Expt. & Commitment & 1,101 & 0,000 & 1,101 & $* * *$ & Accepted \\
\hline H11 & Outcome_Expt. & Performance & 0,576 & $-0,251$ & 0,325 & $* * *$ & Accepted \\
\hline $\mathrm{H} 12$ & Commitment & Performance & $-0,228$ & 0,000 & $-0,228$ & 0,071 & Rejected \\
\hline
\end{tabular}

Source: Appendix 7

Based on Table 4.2 it can be seen that there is paths and significant as well as not significant effects. Thus, the hypotheses which have significant pathways, ehich are accepted and supported by empirical data are:

H1: $\quad$ IT knowledge affects computer self-efficacy

H2: Technical Support affects computer self-efficacy

H3: $\quad$ Ease of IT Use affects computer self-efficacy

H5: Technical Support affects outcome expectations

H6: $\quad$ Ease of IT Use affects outcome expectations

H7: Computer self-efficacy affects outcome expectations

H9: Computer self-efficacy affects end user performance

H10: Outcome expectation affects end user commitment

H11: Outcome expectation affect end user performance

While for the hypotheses of:

H4: IT knowledge affects outcome expectations

H8: Computer self-efficacy affects end user commitment 
H12: End User Commitment affects end user performance is not supported with empirical data and so rejected.

\subsection{Discussion}

Based on the study result analysis, measurements of causal relationship between the constructs shown in Figure 5.1 (second step), which is the optimum models as evidenced from the presence of Chi-square values with probability (p) of 0.095 and RMSEA of 0.016 as well as CFI value of 0.991 . These results proved that the proposed model are in accordance with the data. Thus the model of the relationship between the constructs or latent variables are acceptable

\subsubsection{Influence of knowledge on computer self-efficacy}

Knowledge provide a direct role on computer self-efficacy. As the knowledge of end users will increase end-user confidence in using information technology (computer self-efficacy). This is consistent with previous research, which suggested that knowledge is the main factor affecting end-user confidence (computer self-efficacy) and acquisition of computer skills (Compeau and Higgins, 1995; Nelson and Cheney, 1987).

\subsubsection{Influence of Technical Support on computer self-efficacy}

Technical support provide direct effect on computer self-efficacy. The supports provided by institutions will increase end-user confidence (computer self-efficacy) in using information technology. This is consistent with previous research conducted by Igbaria (1990) which conveyed that the support plays an important role in introducing the end-users to new devices as well as in responding the needs and problems faced by end users.

\subsubsection{Influence of Ease of IT Use on computer self-efficacy}

Ease of IT use provides direct influence on computer self-efficacy. The ease information technology use perceived by end users will increase end-user confidence in using information technology. This is consistent with previous research conducted by Stone and Henry (2003) ehich stated that the ease of IT use provide positive influence on computer self-efficacy, while Davis et al., (1989) stated that the use of the system depends on the ease of IT use.

\subsubsection{Influence of TI knowledge on outcome expectations}

Knowledge does not provide direct effect on outcome expectations. With background of IT knowledge possessed, the end users do not have outcome expectations in performing tasks related to information technology. This means that although the knowledge held by employees are adequate, it is not indicate better work quality, the employee does not want to gain achievement, and the work is not completed on time. This is because the employee curiosity toward the new system and the employee always want to try on the new system so that there is no expectation on the system. These results are contrary to previous research conducted by Stone and Henry (2003) which stated that knowledge provide positive influence on computer self-efficacy and outcome expectations.

\subsubsection{Influence of Technical Support on Outcome Expectations}

Technical support provide direct influence on outcome expectations. With the technical support provided by institution will raise expectations to end users in carrying out tasks related to information technology. This is consistent with previous research conducted by Stone and Henry (2003) which showed that technical support positively affecting end-user commitment through outcome expectancy.

\subsubsection{Influence of Ease of IT Use on Outcome Expectations}

Ease of IT use has direct effect on outcome expectations. With the ease of use of information technology perceived by end user, it will raise expectations for the work related to information technology. This is consistent with previous research conducted by Stone and Henry (2003) which stated that the ease of system use has a positive influence on end-user commitment through outcome expectancy.

\subsubsection{Influence of computer self-efficacy on Outcome Expectations}

Computer self-efficacy gives a direct effect on outcome expectations. The computer self-efficacy perceived by end users will affect their outcome expectations in work related to information technology. This means that if the end users confident with their ability to use a computer, the end user indicates a better quality of work, achievement, and completion of the work that is not timely. This is contrary to previous research conducted by Stone and Henry (2003) which stated that computer self-efficacy positively influences outcome expectations. 


\subsubsection{Influence of computer self-efficacy on end user commitment}

Computer self-efficacy has no direct effect on end user commitment. With the self-efficacy sensed by employees to use IT, it will not affect the their commitment to continuously use information technology. This means that even though the end-user confident with his/her ability to use computer, the end user does not show sympathy in using the system even though the system was beneficial, the he/she will also not be proud toward the system so that there is no sense of belonging of such system. This is because the average age of respondents relatively young and relatively short work experience, at such age and work experience the respondents tend to do trial whenever there is a new system, so that respondents are not committed to one system. These results are contrary to previous research conducted by Stone and Henry (2003) which stated that computer self-efficacy provide positive influence on end-user commitment. At individual level, end-user commitment will result in extraordinary efforts on work, turnover and slowness .

\subsubsection{Influence of computer self-efficacy on end user performance}

Computer self-efficacy gives a direct effect on end users performance. With computer self-efficacy possessed by end users, it will affect their performance. This is consistent with previous research conducted by Stone and Henry (2003) which stated that computer self-efficacy has positive influence on end-user performance.

\subsubsection{Influence of outcome expectation on end user commitment}

Outcome expectation directly affecting end user commitment. With the outcme expectation perceived by end user will affect end user's commitment to continuously use information technology. This is consistent with previous research conducted by Stone and Henry (2003) which stated that the outcome expectation positively influence the end user commitment.

\subsubsection{Influence of outcome expectations on end user performance}

Outcome Expectations give a direct effect on end users performance. With outcome expected by end users, it will affect their performances in the use of information technology. This is consistent with previous research conducted by Smith (2002) which stated that academic performance is influenced by expectations of outcomes and academic goals.

\subsubsection{Influence of end user commitment and end user performance}

End user commitment does not have direct effect on end user performance. The end user commitment end user performance in the use of information technology. This means that even though the end users have perceived benefits of system usability, excited to use the system, having sense of ownership on the system, it is not affect performance of end users in the use of information technology. This is because respondents are employees who work in Information Technology field. Employees who work in IT field have only one kind of skill and the job performed repeatedly, which is different with the employee that has more than one skill. Such employees perform work only for responsibility, and have no purpose to improve performance.

\subsection{Implications for Further Research}

For further researcher who is interesting in examining the same research model, there is expectation that the next researcher is able to develop variables other than knowledge, technical support, ease of use, computer self-efficacy, outcome expectations, end user commitment end-user performance, such as computer experience variables, task characteristics and environmental uncertainty that can affect the end-user confidence. It is also expected the development of existing questionnaires to be able to explore deeper information from respondents. Future studies should also test the relationship between formal education and the characteristics of given task, because end users with lower formal education are able to perform tasks related to the computer which are more simple than those employees with higher education.

Future studies should consider the effect of other computer self-efficacy and other intervening variables that can affect the outcome, thus expanding the existing knowledge regarding the relationship between computer selfefficacy and the establishment of end-user confidence in using computers.

\subsection{Research Limitations}

This study conducted is still far from perfect due to many aspects that have not been included in our model as well as varioues limitations encountered in conducting research in the form of:

1. This study was only conducted in Makassar, so it is expected that this study can also be developed in other areas such as Universities in South Sulawesi Province.

2. Sampling is still limited to administrative staffs only, so it can not be used as a generalization basis for the entire user of information technology in Higher Education Organizations. 
3. This study uses a person's perception measurement to assess attitude and behavior of information technology end user. The use of such data is based on the memory of respondents, it is highly susceptible to bias.

4. As employees, the respondents are still not able to answer questions and express their thoughts perfectly, so that the consistency of the answer is relatively low and they tend to answer what it is. It is also related to their educational background which is still varied.

\subsection{Conclusion}

\section{Conclusion And Suggestions}

In general it can be concluded that variables of information technology knowledge, technical support and ease of information technology use have influence on computer self-efficacy and outcome expectations, which in turn affect the commitment and performance of end users. The influence of each construct is described in detail as follows:

1. Knowledge of information technology, organizational support and ease of information technology use directly affect computer self-efficacy. In this study the variables that have most influence is technical support of computer self-efficacy. Information Technology knowledge variable has a small positive effect in influencing computer self-efficacy. Variable ease of IT use has a small positive effect in influencing computer self-efficacy.

2. Knowledge of information technology, technical support and ease of information technology use directly affect the outcome expectations. In this study the ease of information technology use that has most effect on outcome expectations. Technical support on outcome expectations, the availability of supporting applications are able to affect technical support system which is well developed. End users who are supported or encouraged in the use of computer applications and technical support will have significant effect on the use of information technology. Information Technology knowledge variable have positive insignificant effect on outcome expectations.

3. Computer self-efficacy influence the outcome expectations, end user commitment and end user performance. In this study computer self-efficacy variable mostly affecting the end users performance, and computer self-efficacy on outcome expectations. While the end user commitment has no effect as well as positive effect.

4. Outcome expectations influence on commitment and performance of end users. In this study the end-user commitment variable mostly influenced by the outcome expectations. In this study the end-user commitment variable did not affect the end-user performance.

\subsection{Suggestions}

Based on previous discussion, it can be argued in detail the suggestions, both for knowledge development or for benefit of practical knowledge. As the suggestions of this study are described as follows :

1. Organizations that want to improve their IT investment benefits, through the allocation of training resources for optimal benefits should provide end-users training and equip them with the knowledge and skills required to support the effective use of information technology in the workplace.

2. Outcome expectations should be enhanced as individuals who has high expectations of work outcome will have a tendency to develop higher confidence in the computational capability (computer self-efficacy).

3. Technical support also need to be improved because it also plays an important role in introducing end-users on new devices and in responding to the needs and problems faced by end users. Organization supports also appoint to the importance of peer networking system in encouraging and supporting the end-user through verbal persuasion and "healthy competition".

4. Organizations which expecting the development of end-user capabilities, should consider the implications of which are owned by computer self-efficacy for factors such as effort, persistence, and response to skills development. Organizations also should assist the end users to develop and improve self-confidence in a way that accurately reflects their ability. 


\section{Bibliography}

[1]. Arikunto \& Suharsini. (1988), "Prosedur Penelitian Suatu Pendekatan Praktek", Rineka Cipta, Jakarta

[2]. Bandura (1997), Self-Efficacy: The Exercise of Control, W. H. Freeman and Company, New York NY

[3]. Bandura, A (1986), Social Foundations of Thought and Action: A Social Cognitive Theory, Prentice-Hall, Englewood Cliffs, NJ

[4]. Compeau, Deborah R; \& Higgins, A Christoper (1995), Computer Self-Efficacy: Development of Measure and Initial Test, MIS Quarterly, 19(2), p: 189-211

[5]. Compeau, Deborah R; Higgins, A Christoper; \& Sid, Huff (1999), Social Cognitif Theory and Indi vidual Reaction to Computing Technology: A Longitudinal Study, MIS Quarterly, Jun, 23, 2, p: 145

[6]. Davis, F.D (1986), Perceived Usefulness, Perceived Ease of Use, and User Acceptance of Information Technology. MIS Quarterly, 13(3), p. 319-340

[7]. Davis, F.D., Bagozzi, R., and Warshaw, P, (1989)., "User Acceptance of Computer Technology : A Comparison of Two Theoretical Models". Management Science, Vol. 35, No. 8., 982-1003.

[8]. Davis. F.D. (1993). User Acceptance of Information technology: system characteristics, user perceptions and behavioral impacts. International Journal of Man-Machine Studies. (38). 475-487.

[9]. Hair, J.R, J.F; R.E Anderson; R.L. Tatham; W.C. Black (1995), Multivariate Data Analysis With Reading, Fourth Editions, McMilan Pub. Company. New York

[10]. Hasibuan, M, (2000), Organisasi dan Motivasi, Bumi Aksara, Jakarta

[11]. Henry, J.W, \& Stone, R.W.(1995). A Structural Equation Model of Job Performance Using a Computer-Base Order Entry System. Bahaviour and Information Technology, Vol.14. No.3, pp.163-173

[12]. Henry, John W. \& Stone, Robert W., (1994), A Structural Equation Model of End-User Satisfaction with a Computer-Based Medical Information System, Information Resources Management Journal, Vol. 7, No. 3, pp. 21 - 33

[13]. Henry. J. W., \& Stone, R. W. (1997). The development and validation of computer self-efficacy and outcome expectancy scales in a volitional context. Behavior Research Methods. Instruments and Computers. 29(4). 519-527.

[14]. Igbaria, M (1990), End-User Computing Effectiveness: A Structural Equation Modeling, OMEGA International Journal of Management Science, 18(6), p: 637-652

[15]. Igbaria,M; Guimares, T; Davis, Gordon B (1995), Testing the Determinant of Microcomputer Usage Via Structural Equation Model, Journal of Management Information System, 11, 4, p: 87

[16]. Jawahar, M.I; \& Elango, B (2001), The Effect of Attitude Goal Setting and Self-Efficacy on End-User Performance, Journal of End User Computing, Vol. 13 (2), p:409-45

[17]. Johan dan Wijaya, Toni (2005), Pengaruh Computer Anxiety Terhadap Keahlian Penggunaan Komputer, Jurnal Studi Indonesia

[18]. Malhotra, Y; \& Galletta, Dennis (2005), A Multidimensional Commitment model of Volitional Systems Adoption And Usage Behavior, Journal of Management Information System, Summer, p. 1-47

[19]. Marakas, G., Yi, Mun Y., \& Kats, E. C (1998), The Multilevel and Multifaceted Character of Computer SelfEfficacy: Toward Clarification of The Construct and an Integrative Framework for Research, Information System Research, 9 (2), 126-163

[20]. Smith M. Sheila (2002), The Role of Social Cognitive Career Theory in Information Technology Based Academic Performance, Information Technology, Learning and Performance Journal; Fall, Vol. 20, No.2, ABI/INFORM Global, p. $1-10$

[21]. Stone, R.W; \& Henry, J.W (2003), The Role of Computer Self-Efficacy and Outcome Expectancy in Influencing The Computer End-User's Organizational Commitment, Journal of End-User Computing, 15 (1), p: 38-53 